
High Efficiency Planar $\mathrm{CH}_{3} \mathrm{NH}_{3} \mathrm{Pbl}_{3}$

SUBJECT AREAS: MATERIALS FOR DEVICES MATERIALS CHEMISTRY

Received 30 July 2014

Accepted

3 October 2014

Published

24 October 2014

Correspondence and requests for materials should be addressed to

C.S. (charles.surya@ polyu.edu.hk) \section{Perovskite Solar Cells}

Zhiwei Ren' ', Annie Ng', Qian Shen', Huseyin Cem Gokkaya' , Jingchuan Wang', Lijun Yang ${ }^{2}$, Wai-Kin Yiu ${ }^{3}$, Gongxun Bai ${ }^{4}$, Aleksandra B. Diurišic ${ }^{3}$, Wallace Woon-fong Leung ${ }^{2}$, Jianhua Hao ${ }^{4}$, Wai Kin $\mathrm{Chan}^{5} \&$ Charles Surya

'Department of Electronic and Information Engineering, The Hong Kong Polytechnic University, Hong Kong SAR, ${ }^{2}$ Department of Mechanical Engineering, The Hong Kong Polytechnic University, Hong Kong SAR, ${ }^{3}$ Department of Physics, The University of Hong Kong, Pokfulam, Hong Kong SAR, ${ }^{4}$ Department of Applied Physics, The Hong Kong Polytechnic University, Hong Kong SAR, ${ }^{5}$ Department of Chemistry, The University of Hong Kong, Pokfulam, Hong Kong SAR.

We report investigations on the influences of post-deposition treatments on the performance of solution-processed methylammonium lead triiodide $\left(\mathrm{CH}_{3} \mathrm{NH}_{3} \mathrm{PbI}_{3}\right)$-based planar solar cells. The prepared films were stored in pure $\mathrm{N}_{2}$ at room temperature or annealed in pure $\mathrm{O}_{2}$ at room temperature, $45^{\circ} \mathrm{C}, 65^{\circ} \mathrm{C}$ and $85^{\circ} \mathrm{C}$ for 12 hours prior to the deposition of the metal electrodes. It is found that annealing in $\mathrm{O}_{2}$ leads to substantial increase in the power conversion efficiencies (PCEs) of the devices. Furthermore, strong dependence on the annealing temperature for the PCEs of the devices suggests that a thermally activated process may underlie the observed phenomenon. It is believed that the annealing process may facilitate the diffusion of $\mathrm{O}_{2}$ into the spiro-MeOTAD for inducing p-doping of the hole transport material. Furthermore, the process can result in lowering the localized state density at the grain boundaries as well as the bulk of perovskite. Utilizing thermal assisted $\mathrm{O}_{2}$ annealing, high efficiency devices with good reproducibility were attained. A PCE of $15.4 \%$ with an open circuit voltage $\left(V_{O C}\right) 1.04 \mathrm{~V}$, short circuit current density $\left(J_{S C}\right)$ $23 \mathrm{~mA} / \mathrm{cm}^{2}$, and fill factor 0.64 had been achieved for our champion device.

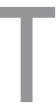

he dramatic emergence of the hybrid inorganic-organic perovskites as a photovoltaic material resulted in a remarkable impact on the field of photovoltaics ${ }^{1-3}$. Such impressive progress in the development of the perovskite-based photovoltaic cells is attributed to the desirable physical properties for this class of materials such as their broadly tunable bandgaps ${ }^{4}$, high absorption coefficients over a wide range of visible light spectrum ${ }^{5}$, extremely long carrier diffusion length $s^{6-7}$, good crystallinity ${ }^{8-9}$ and high carrier mobilities ${ }^{9-11}$, which have fulfilled most of the criteria required for manufacturing high efficiency solar cells. Starting from the first attempt of using perovskite as the sensitizer ${ }^{12}$ for solar cells in 2009, the PCEs of perovskite-based devices have been enhanced from $3.8 \%{ }^{12}$ to around $15 \%{ }^{13-14}$, which represents the most rapid rate of increase in recent years compared to other competing photovoltaic technologies. During the time of the composition of this paper, the PCEs of perovskite solar cells have been further boosted to $16.2 \%$ (certified) and $19.3 \%$ by the efforts of Jeon et al..$^{15}$ and Zhou et al. ${ }^{16}$ With continuing development of the perovskite-based solar cells, the device efficiency which is comparable to the commercial single-crystalline silicon solar cells potentially can be achieved in the near future.

$\mathrm{CH}_{3} \mathrm{NH}_{3} \mathrm{PbI}_{3}$, with a bandgap of $1.5 \mathrm{eV}$, is the most studied perovskite-based photovoltaic material, which has been incorporated into different structures of electron injecting layers such as the compact titanium(IV) oxide $\left(\mathrm{TiO}_{2}\right)$ layer ${ }^{17}$ and mesoporous $\mathrm{TiO}_{2}$ layer ${ }^{14,18-21}$ or combined with one-dimensional nanostructures such as $\mathrm{TiO}_{2}$ nanorods ${ }^{22}$, nanofibers ${ }^{23}$ and $\mathrm{ZnO}$ nanorods ${ }^{24-26}$ for the formation of high efficiency photovoltaic cells. Due to the fact that the architecture of the perovskite solar cells evolved from mesoscopic dye-sensitized solar cells (DSSCs), tremendous research efforts of employing perovskite absorbers have been initially focused on $\mathrm{TiO}_{2}$ mesostructures yielding PCEs as high as $15 \%$ for $\mathrm{CH}_{3} \mathrm{NH}_{3} \mathrm{PbI}_{3}$ based perovskite devices ${ }^{14}$. However, as demonstrated by $\mathrm{M}$. M. Lee et al. ${ }^{8}$ and J. M. Ball et al. ${ }^{27}$ high PCE can also be achieved even if the mesoporous $\mathrm{TiO}_{2}$ is replaced with an insulating alumina $\left(\mathrm{Al}_{2} \mathrm{O}_{3}\right)$ mesoscopic scaffold. Due to the higher conduction band of $\mathrm{Al}_{2} \mathrm{O}_{3}$ compared to the lowest unoccupied molecular orbital (LUMO) of the perovskite layer, it is not possible for the electrons to be injected from the perovskite layer into the $\mathrm{Al}_{2} \mathrm{O}_{3}$ scaffold indicating that the photoexcited electrons are trans- 
ported through the perovskite layer ${ }^{8}$. This discovery raises the question of whether the $\mathrm{TiO}_{2}$ mesostructure is necessary to achieve high efficiency perovskite solar cells. Recently, several research groups have demonstrated efficient perovskite solar cells in a planar structure without the mesoscopic scaffold ${ }^{13,17,28-34}$. This type of architecture allows for much simpler fabrication process, minimizes the chance of charge recombination at the interfaces and can be compatible with multijunction in hybrid tandem solar cells.

Among the published works, mixed halide perovskites ${ }^{13,32-34}$ (e.g. $\mathrm{CH}_{3} \mathrm{NH}_{3} \mathrm{PbI}_{3-\mathrm{x}} \mathrm{Cl}_{\mathrm{x}}$ ) or $\mathrm{CH}_{3} \mathrm{NH}_{3} \mathrm{PbI}_{3}{ }^{17}$ are commonly employed in the planar structure with compact $\mathrm{TiO}_{2}$ as the hole blocking layer, yielding the highest PCE of $15.4 \%$ for vapor deposited $\mathrm{CH}_{3} \mathrm{NH}_{3} \mathrm{PbI}_{3-\mathrm{x}} \mathrm{Cl}_{\mathrm{x}}$-based device ${ }^{13}$ and $12.1 \%$ for $\mathrm{CH}_{3} \mathrm{NH}_{3} \mathrm{PbI}_{3}$-based device prepared by vapor-assisted solution process ${ }^{17}$. Although a number of reports have demonstrated significant potential in obtaining high efficiency perovskite-based solar cells, the group-to-group, or even batch-to-batch, variations in the reported PCEs is substantial which is believed to arise from the high sensitivity to the fabrication techniques and ambient during the formation of the active layers of the devices. Further development in the field of perovskite-based photovoltaics demands the establishment of a series of optimized and controllable fabrication procedures for yielding highly efficient and reproducible devices.

In this work, we have investigated planar heterojunction devices with a structure that consists of glass/fluorine-doped tin oxide (FTO) $/ \mathrm{TiO}_{2}$ compact layer $/ \mathrm{CH}_{3} \mathrm{NH}_{3} \mathrm{PbI}_{3} / 2,2^{\prime} 7,7^{\prime}$-tetrakis(N,N-dip-methoxyphenyl-amine)-9,9' -spirobifluorene (spiro-MeOTAD)/ molybdenum(VI) oxide $\left(\mathrm{MoO}_{3}\right)$ /aluminum (Al) as illustrated in Fig. 1a. The perovskite films are prepared by sequential two- step solution processed deposition method ${ }^{14}$. Two post-deposition treatments were investigated. The devices were annealed in dry $\mathrm{O}_{2}$ for a period of 12 hours at 4 different temperatures: room temperature (ART); $45^{\circ} \mathrm{C}(\mathrm{A} 45) ; 65^{\circ} \mathrm{C}(\mathrm{A} 65)$; and $85^{\circ} \mathrm{C}(\mathrm{A} 85)$. An annealing time of 12 hours was chosen to ensure that the oxidation process is complete. The annealing time can be further optimized and has to be shortened to enhance the cost-effectiveness of the process. The control samples (NRT) were stored in $\mathrm{N}_{2}$ at room temperature for 12 hours before the deposition of metal electrodes. It is observed that the performances of perovskite-based devices are strongly affected by the post-deposition treatments of the films. Through careful control of the fabrication processes, a highest PCE of $15.4 \%$ was achieved. The processing conditions, post-deposition treatments and corresponding results will be discussed in detail, which are essential for the future development of perovskite-based solar cells.

\section{Results}

$\mathrm{CH}_{3} \mathrm{NH}_{3} \mathrm{PbI}_{3}$-based solar cells have been fabricated and the device configuration is illustrated in Fig. 1a. The broad absorption spectrum of $\mathrm{CH}_{3} \mathrm{NH}_{3} \mathrm{PbI}_{3}$ is shown in Fig. 1b, indicating the strong photon harvesting capability of the material over the spectral range from $400 \mathrm{~nm}$ to $800 \mathrm{~nm}$, which is in agreement with the band gap of $1.5 \mathrm{eV}$ for $\mathrm{CH}_{3} \mathrm{NH}_{3} \mathrm{PbI}_{3}{ }^{18,35}$. The inset of Fig. $1 \mathrm{~b}$ is a photograph of a $\mathrm{CH}_{3} \mathrm{NH}_{3} \mathrm{PbI}_{3}$ film on the FTO coated glass substrate. The prepared film with smooth and reflective surface can be clearly observed by naked eyes, which is believed to be a desirable quality for the development of high performance devices ${ }^{31}$. The morphology and cross section of the samples have been investigated by scanning electron microscopy (SEM) and the images of typical films (A65) are presented in Fig. 2. From the plan-view image of $\mathrm{CH}_{3} \mathrm{NH}_{3} \mathrm{PbI}_{3}$ formed on $\mathrm{TiO}_{2}$ compact layer, crystalline domains of perovskite with grain size in the range of $\sim 100 \mathrm{~nm}$ to $\sim 800 \mathrm{~nm}$ with good surface coverage is observed. High surface coverage is of great importance for high performance devices as undesired shunting paths are minimized and thereby maximizing photo-carrier collection ${ }^{34}$. Furthermore, crystals with large grain size are shown to be favorable for charge transport ${ }^{17,36}$ and may serve as light scattering centers ${ }^{29}$ a)

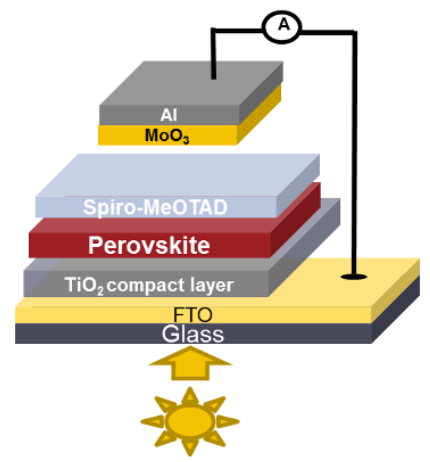

b)

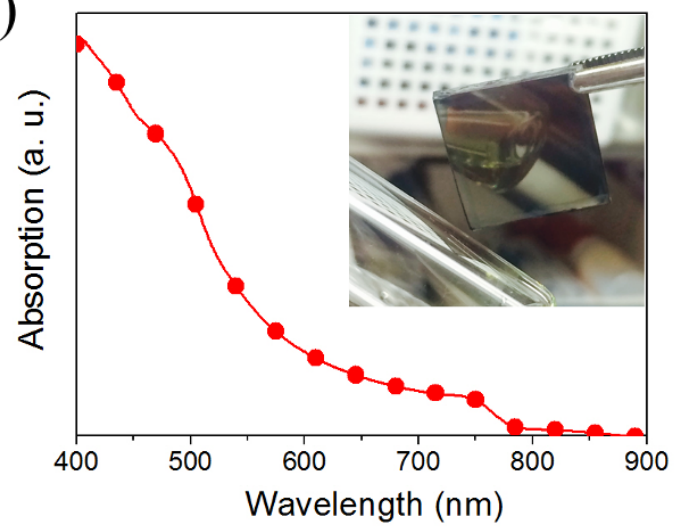

Figure $1 \mid$ (a) The device architecture of $\mathrm{CH}_{3} \mathrm{NH}_{3} \mathrm{PbI}_{3}$ based solar cell (b) absorption spectra of $\mathrm{CH}_{3} \mathrm{NH}_{3} \mathrm{PbI}_{3}$ before and after $\mathrm{O}_{2}$ post-deposition treatments.

and are, therefore, preferable for the development of high performance devices. The cross-sectional SEM image of a typical device without the top electrode is shown in Fig. 2b. The thicknesses of the solution-processed $\mathrm{CH}_{3} \mathrm{NH}_{3} \mathrm{PbI}_{3}$ and spiro-MeOTAD layers are around $410 \mathrm{~nm}$ and $190 \mathrm{~nm}$ respectively, which are in the range of the reported values for achieving high efficiency devices ${ }^{8,14,19}$. The surface morphologies of $\mathrm{PbI}_{2}$ and $\mathrm{CH}_{3} \mathrm{NH}_{3} \mathrm{PbI}_{3}$ with or without the spiro-MeOTAD layer on top have been characterized by atomic force microscopy (AFM) and the results are shown in Fig. 3. It is found that the root mean square (RMS) roughness significantly increases from $25 \mathrm{~nm}$ to $31 \mathrm{~nm}$ after the $\mathrm{PbI}_{2}$ and the $\mathrm{CH}_{3} \mathrm{NH}_{3} \mathrm{I}$ layers were allowed to react to form $\mathrm{CH}_{3} \mathrm{NH}_{3} \mathrm{PbI}_{3}$. An increase in the grain size is observed subsequent to the formation of $\mathrm{CH}_{3} \mathrm{NH}_{3} \mathrm{PbI}_{3}$, which is attributed to the volume expansion ${ }^{17,37}$ commonly observed in the process. The surface roughness of $\mathrm{CH}_{3} \mathrm{NH}_{3} \mathrm{PbI}_{3}$ with the hole transport layer (HTL, spiro-MeOTAD) on top is reduced to $5 \mathrm{~nm}$, indicating that the perovskite layer is fully covered and hence short-circuit currents due to the direct contact between the relatively conductive perovskite $\left(\sim 10^{-3} \mathrm{~S} \mathrm{~cm}^{-1}\right)$ and metal electrode can be avoided ${ }^{8}$. The samples of $\mathrm{CH}_{3} \mathrm{NH}_{3} \mathrm{PbI}_{3}$ deposited on glass or compact $\mathrm{TiO}_{2}$ coated FTO substrates were further characterized by X-ray diffraction (XRD) and the diffraction patterns are shown in Fig. 4. Strong diffraction peaks located at $14.0^{\circ}, 28.5^{\circ}$ and $31.8^{\circ}$ for $2 \theta$ scan were observed corresponding to the planes of (110), (220) and (310), which are in good agreement with the previous reports ${ }^{17,14,38}$, indicating that the tetragonal perovskite structure is formed ${ }^{5,12,37}$.

The $\mathrm{CH}_{3} \mathrm{NH}_{3} \mathrm{PbI}_{3}$-based planar devices were fabricated in an $\mathrm{N}_{2^{-}}$ filled glove box $\left(\mathrm{O}_{2}\right.$ and $\left.\mathrm{H}_{2} \mathrm{O}<0.1 \mathrm{ppm}\right)$ since the perovskite materials are easily decomposed in the presence of moisture ${ }^{39}$. However, we found that the devices exhibit poor performance when the entire fabrication processes were carried out in the glove box. This is attributed to the poor doping conditions for the spiro-MeOTAD layer as it 


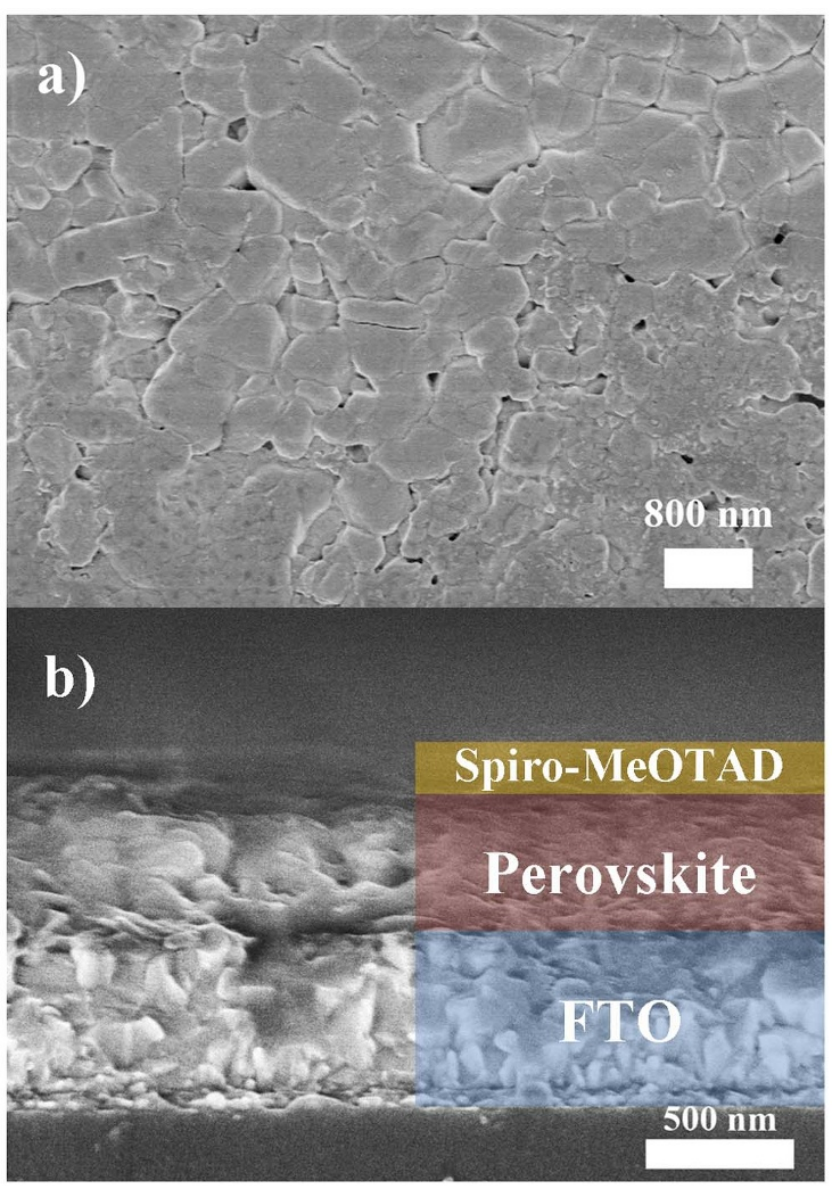

Figure $2 \mid$ (a) Top-view and (b) cross-sectional SEM images for the sample of $\mathrm{FTO} / \mathrm{TiO}_{2} / \mathrm{CH}_{3} \mathrm{NH}_{3} \mathrm{PbI}_{3} /$ spiro-MeOTAD.

was pointed out that $\mathrm{O}_{2}$ may be essential for the doping mechanism of spiro-MeOTAD ${ }^{40-42}$. We have performed $I-V$ measurements on the spiro-MeOTAD film using the Transfer Length Method (TLM). Resistances across the electrodes with different separations are shown in Fig. 5. The results clearly indicate significant reduction in the resistance of the spiro-MeOTAD layer annealed in $\mathrm{O}_{2}$ ambient. This is indicative of improved doping level for the annealed film. Similar observations of reduction in the cell efficiency for solid-state dye-sensitized solar cells fabricated in $\mathrm{N}_{2}$ had also been reported previously ${ }^{42}$. This situation differs from the fabrication of organic devices, such as organic light emitting devices and organic solar cells, for which exposure to $\mathrm{O}_{2}$ should be avoided as it can lead to severe device degradation ${ }^{43,44}$. Considering the fact that moisture is highly devastating to the performance of perovskite-based devices while $\mathrm{O}_{2}$ is necessary for obtaining high efficiency devices, we deposited all the different layers of the device in $\mathrm{N}_{2}$-filled glove box to prevent the exposure to moisture, after that the prepared samples were annealed in dry $\mathrm{O}_{2}$ (high purity grade, $>99.9 \%$ ) for 12 hours at different annealing temperatures.

The photovoltaic parameters of $\mathrm{CH}_{3} \mathrm{NH}_{3} \mathrm{PbI}_{3}$-based devices with different post-deposition treatments are summarized in Table 1 while the $I-V$ curves of the representative devices, which are close to the average performance for each post-deposition condition, are presented in Fig. 6a. The experimental data demonstrates substantial enhancement in the PCE (from $6.0 \%$ to $8.5 \%$ ) for the ART-devices compared to the control devices (NRT-devices). The device performances were further improved when the samples were annealed in $\mathrm{O}_{2}$ at an elevated temperature. Under the optimized temperature $\left(65^{\circ} \mathrm{C}\right)$, the $J_{S C}$ and fill factor of the A65-devices are significantly a)

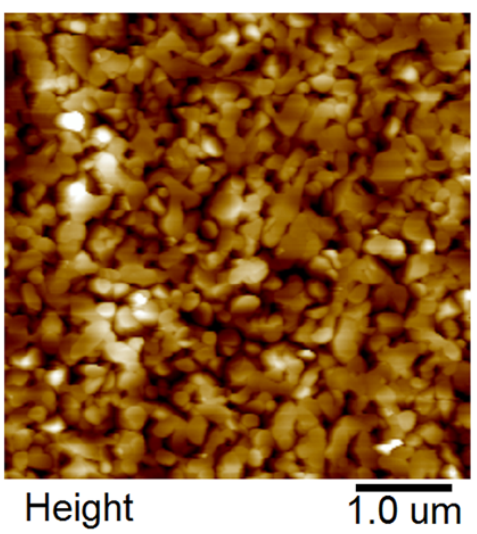

$183.4 \mathrm{~nm}$

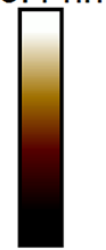

$0 \mathrm{~nm}$

b)

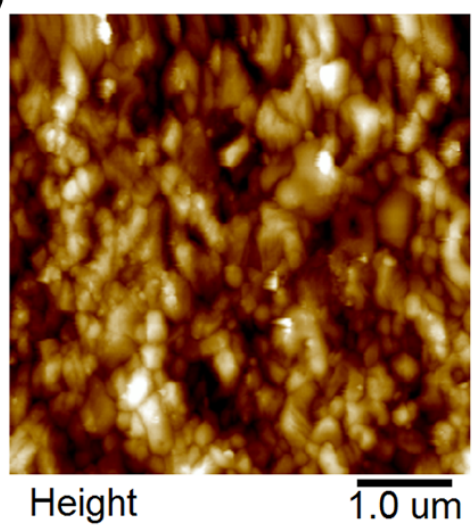

201

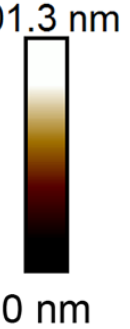

c)

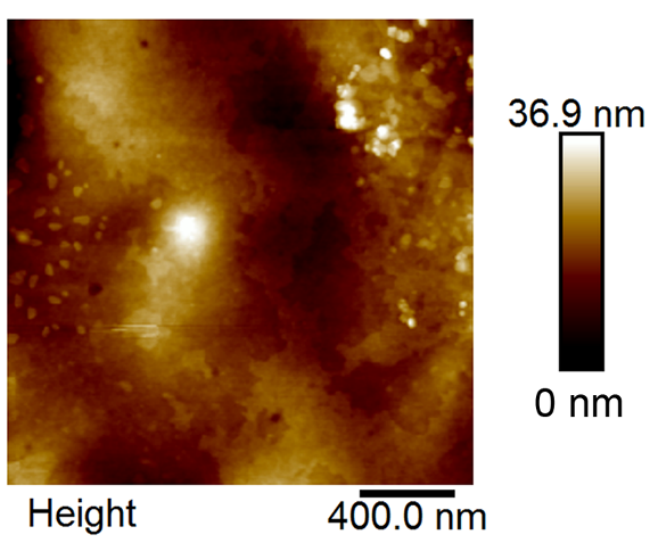

Figure 3 AFM images for (a) $\mathrm{PbI}_{2}$ (RMS: $25 \mathrm{~nm}$ ) (b) $\mathrm{CH}_{3} \mathrm{NH}_{3} \mathrm{PbI}_{3}$ (RMS: $31 \mathrm{~nm}$ ) and (c) $\mathrm{CH}_{3} \mathrm{NH}_{3} \mathrm{PbI}_{3} /$ spiro-MeOTAD (RMS: $5 \mathrm{~nm}$ ).

enhanced, yielding an average PCE of $12.0 \%$. Since there is no obvious change in surface morphology and absorption as observed from SEM (Fig. S1) and absorption measurement (Fig. 1b) before and after $\mathrm{O}_{2}$ annealing process, the improvement in device performance is believed to originate from the lowering of the defect densities of the perovskite films. It is believed that the thermal annealing process may facilitate the diffusion of $\mathrm{O}_{2}$ to the perovskite film as well as the material interfaces to passivate the under-coordinated cations of the perovskite layer leading to the reduction in the density of the trap states and thereby reducing the recombination rate, which is reflected by the trend of obtained $J_{S C}$ shown in Fig. 6a. It is found that the $J_{S C}$ of the devices strongly depends on the post-deposition treatments, which is observed to increase from an average of $11.7 \mathrm{~mA} / \mathrm{cm}^{2}$ for NRT-devices to $21.0 \mathrm{~mA} / \mathrm{cm}^{2}$ for A65-devices, suggesting that charges can be extracted more efficiently, likely due to the inhibition of charge recombination at the trap states. Similar 


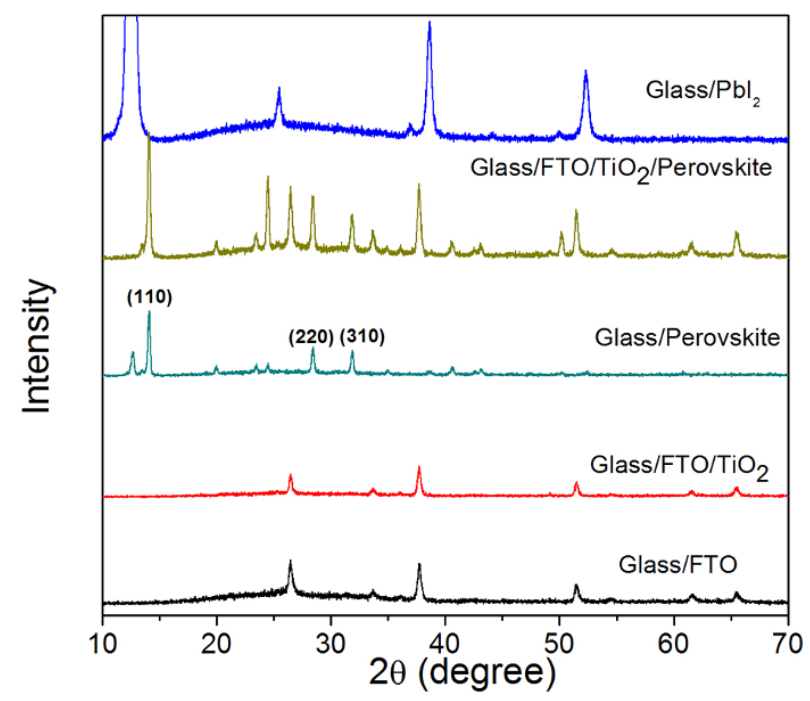

Figure $4 \mid$ XRD patterns for the sample with different layers on glass or FTO coated glass.

work for passivation of halide anions resulting in improved device performance has also been reported previously ${ }^{45}$. However, further increasing the thermal annealing temperature to $85^{\circ} \mathrm{C}$ resulted in a drop in the $J_{S C}$, fill factor and accordingly PCE, which is possibly due to thermally induced degradation of the materials. Besides, a decrease in the magnitude of the $J_{S C}$ for the NRT-devices for $V<0.3 \mathrm{~V}$ is observed, which could be attributed to the low conductivity of spiroMeOTAD and high density of interface states in the absence of $\mathrm{O}_{2}$ annealing, resulting in poor charge collection efficiency. It should be noted that hysteresis effect is generally observed in the $I-V$ characteristics of all our devices, which basically remains unchanged even after the $\mathrm{O}_{2}$ annealing process. This suggests that the $\mathrm{O}_{2}$ annealing process is not able to eliminate the processes/defects responsible for the observed hysteresis effect. The $I-V$ curves shown in the figures were obtained from the reverse scan at the scan rate of $0.01 \mathrm{~V} / \mathrm{s}$ from $1.2 \mathrm{~V}$ to $-0.2 \mathrm{~V}$.

The EQE spectra of $\mathrm{CH}_{3} \mathrm{NH}_{3} \mathrm{PbI}_{3}$-based devices with different post-deposition treatments are shown in Fig. 6b, which demonstrate wide spectral response from $400 \mathrm{~nm}$ to $800 \mathrm{~nm}$ in good agreement with the absorption spectra shown in Fig. 1b. The trend of the EQE spectra is also consistent with the $I-V$ performance of the devices. There is a significant enhancement in EQE for the ART and A45 devices compared to the NRT devices. The EQE is further enhanced for the samples annealed in dry $\mathrm{O}_{2}$ at $65^{\circ} \mathrm{C}$ while further increasing the annealing temperature to $85^{\circ} \mathrm{C}$ in the presence of $\mathrm{O}_{2}$ results in a reduction in the EQE. It is interesting to point out that a drop in the $\mathrm{EQE}$ results in the short wavelength range is typically attributed to high concentration of defect states in the front heterojunction. Detailed comparison between the EQE data for the control device (NRT) and the annealed device under optimal conditions (A65) we observe significant improvement in the EQE results at the short wavelength range. In general, the reduction in the EQE of solar cells can be attributed to charge recombination and short charge carrier diffusion length ${ }^{46}$, unequal enhancement in EQE along the spectrum is likely to occur when the condition of post-deposition treatment has not been completely optimized and considerable amount of traps still exist. It appears that $\mathrm{O}_{2}$ annealing may lead to an improvement in the carrier collection efficiency across the $\mathrm{TiO}_{2} /$ perovskite interface ${ }^{47}$ and the grain boundaries within the perovskite layer.

Detailed characterization of the time-resolved photoluminescence signal has been performed for both the control sample and the perovskite film annealed in $\mathrm{O}_{2}$ ambient at $65^{\circ} \mathrm{C}$. The films were deposited directly on quartz substrates in order to pinpoint the effects of

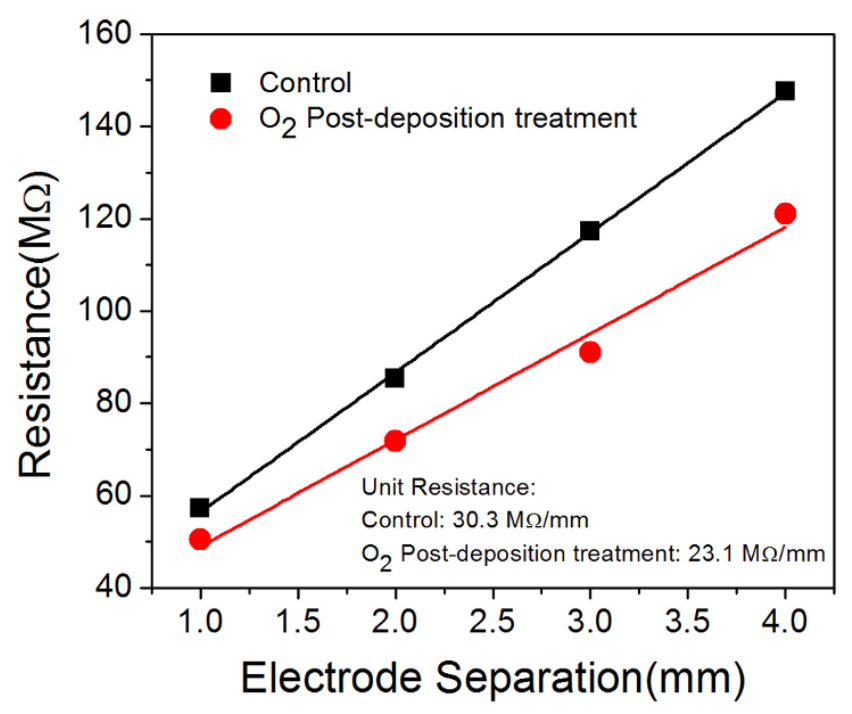

Figure 5 $\mid$ The resistance of the film of spiro-MeOTAD across the electrodes with and without $\mathrm{O}_{2}$ post-deposition treatments.

the $\mathrm{O}_{2}$ annealing process on the perovskite film. The experimental data are shown in Fig. 7. It is clear from the data that two separate lifetimes exist in the annihilation of the PL signal indicative of the presence of two recombination pathways ${ }^{48}$. Substantial improvements in the carrier lifetimes are observed in the $\mathrm{O}_{2}$ annealed sample indicating significant reduction in the density of the localized states in the perovskite film, which is consistent with the results of device performance. It is likely that most of these localized states reside at the grain boundaries however based on the data alone it is not possible to identify the specific location of the trap states. Further work needs to be done to specifically identify the mechanism underlying the observed phenomenon.

By adopting the strategy of thermally assisted $\mathrm{O}_{2}$ annealing of the deposited films, a champion device with a PCE as high as $15.4 \%$ and a high $J_{S C}$ of $23 \mathrm{~mA} / \mathrm{cm}^{2}$ can be achieved and the corresponding $I-V$ curves are shown in Fig. 8. It is noted that the reproducibility of the perovskite-based solar cells can be significantly improved by postdeposition treatments, which is reflected by the lower values in the standard deviations in the photovoltaic parameters indicated in Table 1. The proposed fabrication strategy is straightforward and controllable for assembling highly efficient and good reproducible perovskite-based solar cells.

\section{Discussion}

$\mathrm{CH}_{3} \mathrm{NH}_{3} \mathrm{PbI}_{3}$-based devices have been fabricated under well controlled fabrication procedures. Our work demonstrated that postdeposition $\mathrm{O}_{2}$ treatments are critical, which not only enhance the device performance substantially, but also improve the device reproducibility. We found that placing the solution-processed films in dry $\mathrm{O}_{2}$ at $65^{\circ} \mathrm{C}$ prior to electrode deposition is an essential process for device fabrication, yielding an averaged enhanced PCE of $12 \%$. Our results suggest that the improvement in device performance by $\mathrm{O}_{2}$ annealing process is due to the enhancement in the conductivity of spiro-MeOTAD as well as the reduction in the defect density of the perovskite film.

\section{Methods}

Materials. Patterned FTO coated glass substrates with a sheet resistance of 7-10 $\Omega / \square$ were supplied from KINTEC company. Lead (II) iodide (purity $99 \%, \mathrm{PbI}_{2}$ ), titanium (IV) isopropoxide (TTIP), lithium bis(trifluoromethylsulphonyl)imide (Li-TFSI), 4tert-butylpyridine (tBP), N,N-dimethylformamide (DMF) and $\mathrm{MoO}_{3}$ were purchased from Sigma-Aldrich while spiro-MeOTAD (purity $>99.5 \%$ ) was purchased from Luminescence Technology Corp. Methylammonium iodide $\left(\mathrm{CH}_{3} \mathrm{NH}_{3} \mathrm{I}\right)$ was purchased from Dyenamo. All chemicals were used as received. 
Table 1 | The average values of photovoltaic parameters obtained from I-V measurements for planar $\mathrm{CH}_{3} \mathrm{NH}_{3} \mathrm{Pbl}_{3}$ based solar cells with different post-deposition treatments and integrated photocurrent from the EQE spectra are indicated in the bracket

\begin{tabular}{|c|c|c|c|c|c|}
\hline Type & $V_{O C}(\mathrm{~V})$ & $\begin{array}{c}J_{S C} \\
\left(\mathrm{~mA} / \mathrm{cm}^{2}\right)\end{array}$ & $\mathrm{FF}$ & $\eta(\%)$ & $\Delta \eta(\%)$ \\
\hline NRT & $0.96 \pm 0.02$ & $\begin{array}{l}11.7 \pm 4.0 \\
(10.6)\end{array}$ & $0.48 \pm 0.20$ & $6.0 \pm 3.7$ & - \\
\hline ART & $0.90 \pm 0.12$ & $\begin{array}{l}19.5 \pm 1.2 \\
(15.3)\end{array}$ & $0.48 \pm 0.09$ & $8.5 \pm 2.6$ & 42 \\
\hline A45 & $0.99 \pm 0.03$ & $\begin{array}{l}19.3 \pm 0.4 \\
(15.6)\end{array}$ & $0.48 \pm 0.03$ & $9.2 \pm 0.9$ & 53 \\
\hline A65 & $0.98 \pm 0.01$ & $\begin{array}{l}21.0 \pm 0.5 \\
(20.5)\end{array}$ & $0.57 \pm 0.03$ & $12.0 \pm 0.7$ & 100 \\
\hline A85 & $0.97 \pm 0.02$ & $\begin{array}{l}17.9 \pm 2.6 \\
(14.0)\end{array}$ & $0.49 \pm 0.02$ & $8.6 \pm 1.0$ & 43 \\
\hline
\end{tabular}

Device fabrication. Patterned FTO on glass substrates were cleaned sequentially by ultrasonication in toluene, acetone, ethanol and deionized water. The substrates were dried by the nitrogen flow and then exposed to UV-ozone for $20 \mathrm{~min}$ prior to the spin coating step. $\mathrm{TiO}_{2}$ compact layer was prepared by spin coating a mildly acidic diluted TTIP solution $(1.25 \mathrm{ml})$ in ethanol $(25 \mathrm{ml})$ at $3000 \mathrm{rpm}$ followed by sintering at $450^{\circ} \mathrm{C}$ for 2 hours. $\mathrm{CH}_{3} \mathrm{NH}_{3} \mathrm{PbI}_{3}$ was synthesized by a two-step technique ${ }^{14}$ with optimized solution concentrations in $\mathrm{N}_{2}$ filled glove box. $\mathrm{PbI}_{2}$ films were prepared by spin coating a solution of $\mathrm{PbI}_{2}(1500 \mathrm{rpm})$ dissolved in $\mathrm{DMF}$ with a concentration of $462 \mathrm{mg} / \mathrm{ml}$ which were then annealed on a hotplate at $70^{\circ} \mathrm{C}$ for 1 hour prior to the

a)

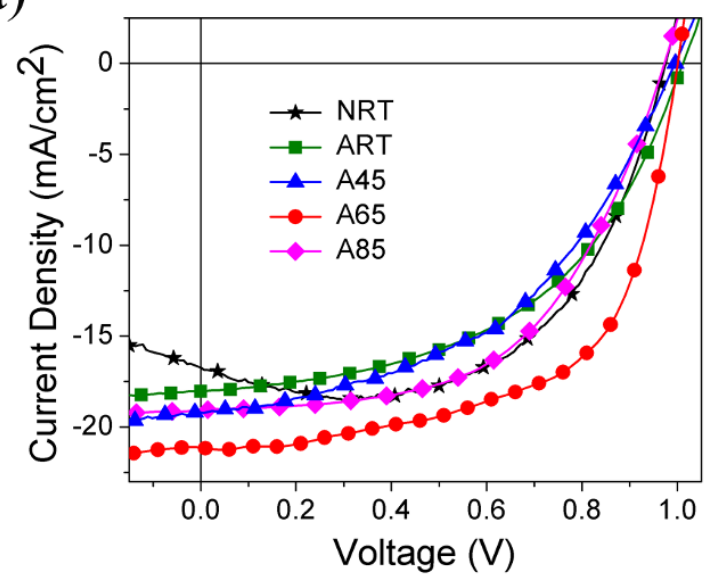

b)

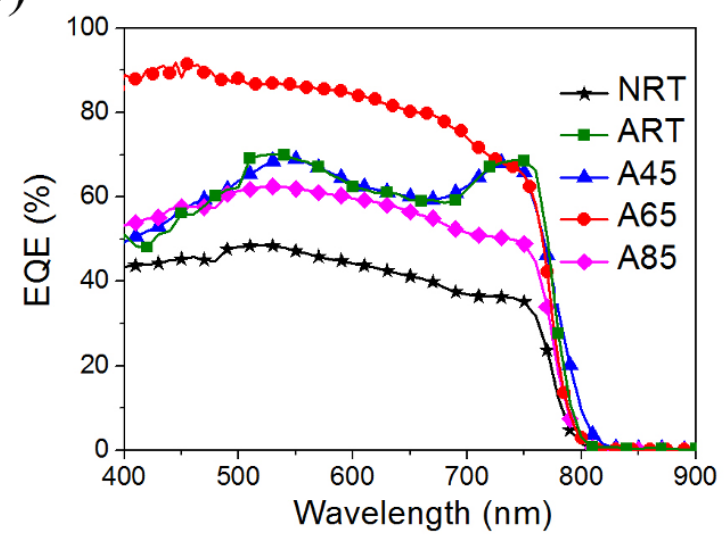

Figure $6 \mid$ (a) The $I$ - $V$ curves and (b) EQE for representative devices with different post-deposition treatments.

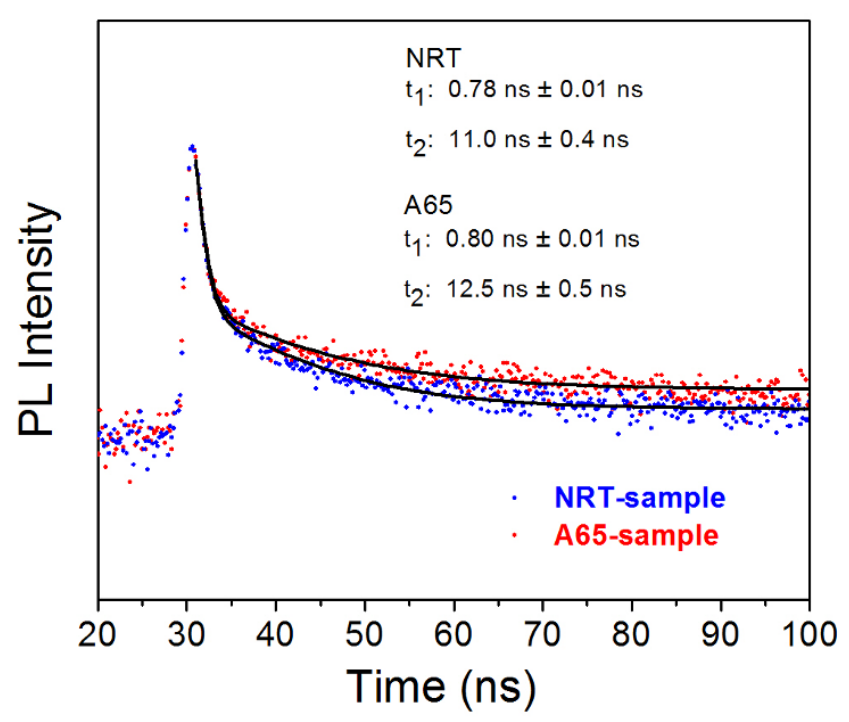

Figure $7 \mid$ The time-resolved photoluminescence of the bare perovskite film with or without $\mathrm{O}_{2}$ post-deposition treatment.

reaction with $\mathrm{CH}_{3} \mathrm{NH}_{3} \mathrm{I}(30 \mathrm{mg} / \mathrm{ml}$ in isopropanol). The samples were then annealed at $90^{\circ} \mathrm{C}$ to ensure complete reaction between $\mathrm{PbI}_{2}$ and $\mathrm{CH}_{3} \mathrm{NH}_{3} \mathrm{I}$. The hole transport layer (HTL) was prepared by spin coating a solution of spiro-MeOTAD $(80 \mathrm{mg} / \mathrm{ml})$ dissolved in chlorobenzene with the additives of Li-TFSI $(17.5 \mu \mathrm{L}$ from a stock solution of $520 \mathrm{mg} / \mathrm{ml}$ in acetonitrile) and $29 \mu \mathrm{L}$ of tBP at $4500 \mathrm{rpm}$. The prepared samples were then stored in $\mathrm{N}_{2}$ ambient at room temperature or in $\mathrm{O}_{2}$ (high purity grade $>99.9 \%$ ) ambient at a flow rate of $2 \mathrm{lit} / \mathrm{min}$ at room temperature, $45^{\circ} \mathrm{C}, 65^{\circ} \mathrm{C}$ or $85^{\circ} \mathrm{C}$ for 12 hours. Electrodes $\left(\mathrm{MoO}_{3}(15 \mathrm{~nm}) / \mathrm{Al}(120 \mathrm{~nm})\right)$ were then deposited by thermal evaporation through a shadow mask and the device area was $0.1 \mathrm{~cm}^{2}$.

Device and sample characterizations. The $I-V$ characteristics of the devices were measured using a B1500 A semiconductor parameter analyzer under the calibrated ABET Technologies SUN 2000 solar simulator equipped with an AM 1.5 filter at $100 \mathrm{~mW} / \mathrm{cm}^{2}$. The $I-V$ curves are obtained from the reverse scan at the scan rate of $0.01 \mathrm{Vs}^{-1}$ from $1.2 \mathrm{~V}$ to $-0.2 \mathrm{~V}$. External quantum efficiency (EQE) was determined by a QE system from Enli Technology Co. Ltd. The surface morphologies of the films were characterized by atomic force microscopy (AFM) in the tapping mode using a Bruker NanoScope 8. UV-visible spectroscopy was performed by using a UV-2550 Shimadzu UV-VIS spectrophotometer for the perovskite film deposited on quartz. Xray diffraction (XRD) patterns was determined by using a Rigaku SmartLab X-ray diffractometer in a step of $0.01^{\circ}$ for $2 \theta$ from $10^{\circ}$ to $70^{\circ}$. Scanning electron microscopy (SEM) was performed by using Hitachi S-4800 field emission scanning electron microscope. Time-resolved photoluminescence signals of perovskite film were monitored at $775 \mathrm{~nm}$ and recorded by using Edinburgh FLSP920 spectrophotometer equipped with the excitation source of $485 \mathrm{~nm}$ picosecond pulsed diode laser.

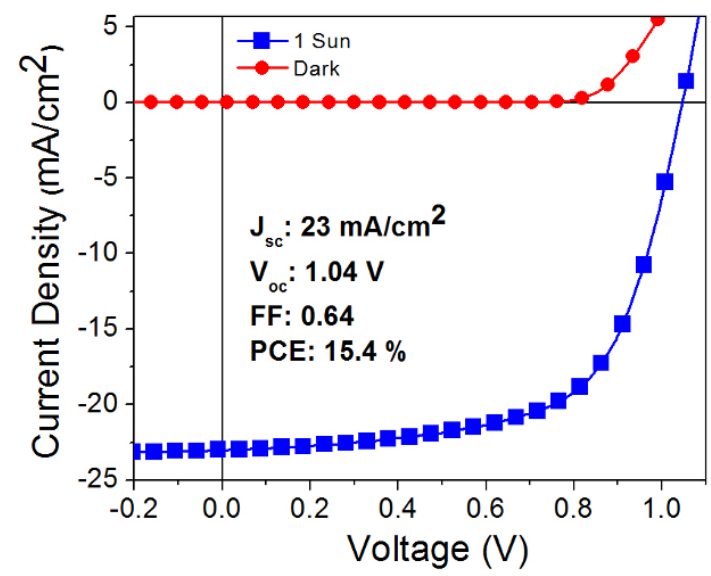

Figure $8 \mid$ (a) The $I-V$ curve of the best device measured at $100 \mathrm{~mW} / \mathrm{cm}^{2}$ and in dark. 
1. Kim, H.-S., Im, S. H. \& Park, N.-G. Organolead halide perovskite: New horizons in solar cell research. J. Phys. Chem. C 118, 5615-5625 (2014).

2. Boix, P. P., Nonomura, K., Mathews, N. \& Mhaisalkar, S. G. Current progress and future perspectives for organic/inorganic perovskite solar cells. Mater. Today 17, 16-23 (2014).

3. Snaith, H. J. Perovskites: The emergence of a new era for low-cost, high efficiency solar cells. J. Phys. Chem. Lett. 4, 3623-3630 (2013).

4. Eperon, G. E. et al. Formamidinium lead trihalide: a broadly tunable perovskite for efficient planar heterojunction solar cells. Energy Environ. Sci. 7, 982-988 (2014).

5. Im, J.-H., Lee, C.-R., Lee, J.-W, Park, S.-W. \& Park, N.-G. 6.5\% efficient perovskite quantum-dot-sensitized solar cell. Nanoscale 3, 4088-4093 (2011)

6. Stranks, S. D. et al. Electron-hole diffusion lengths exceeding 1 micrometer in an organometal trihalide perovskite absorber. Science 342, 341-344 (2013).

7. Xing, G. et al. Long-range balanced electron- and hole-transport lengths in organic-inorganic $\mathrm{CH}_{3} \mathrm{NH}_{3} \mathrm{PbI}_{3}$. Science 342, 344-347 (2013).

8. Lee, M. M., Teuscher, J., Miyasaka, T., Murakami, T. N. \& Snaith, H. J. Efficient hybrid solar cells based on meso-superstructured organometal halide perovskites. Science 338, 643-647 (2012)

9. Stoumpos, C. C., Malliakas, C. D. \& Kanatzidis, M. G. Semiconducting tin and lead iodide perovskites with organic cations: Phase transitions, high mobilities, and near-infrared photoluminescent properties. Inorg. Chem. 52, 9019-9038 (2013).

10. Hodes, G. Perovskite-based solar cells. Science 342, 317-318 (2013).

11. Mitzi, D. B. Synthesis, Structure, and Properties of Organic-Inorganic Perovskites and Related Materials. Prog. Inorg. Chem. 48, 1-121 (2007).

12. Kojima, A., Teshima, K., Shirai, Y. \& Miyasaka, T. Organometal halide perovskites as visible-light sensitizers for photovoltaics cells. J. Am. Chem. Soc. 131, 6050-6051 (2009).

13. Liu, M., Johnston, M. B. \& Snaith, H. J. Efficient planar heterojunction perovskite solar cells by vapour deposition. Nature 501, 395-398 (2013).

14. Burschka, J. et al. Sequential deposition as a route to high-performance perovskite-sensitized solar cells. Nature 499, 316-319 (2013).

15. Jeon, N. J. et al. Solvent engineering for high-performance inorganic-organic hybrid perovskite solar cells. Nat. Mater. 13, 897-903 (2014).

16. Zhou, H. et al. Interface engineering of highly efficient perovskite solar cells. Science 345, 542-546 (2014)

17. Chen, Q. et al. Planar heterojunction perovskite solar cell via vapor-assisted solution process. J. Am. Chem. Soc. 136, 622-625 (2014).

18. Kim, H.-S. et al. Lead iodide perovskite sensitized all-solid-state submicron thin film mesoscopic solar cells with efficiency exceeding 9\%. Sci. Rep. 2, 591; DOI:10.1038/srep00591 (2012).

19. $\mathrm{Bi}, \mathrm{D}$. et al. Using a two-step deposition technique to prepare perovskite $\left(\mathrm{CH}_{3} \mathrm{NH}_{3} \mathrm{PbI}_{3}\right)$ for thin film solar cells based on $\mathrm{ZrO}_{2}$ and $\mathrm{TiO}_{2}$ mesostructures. RCS Adv. 3, 18762-18766 (2013).

20. Heo, J. H. et al. Efficient inorganic-organic hybrid heterojunction solar cells containing perovskite compound and polymeric hole conductor. Nat. Photonics 7, 486-491 (2013)

21. Christians, J. A., Fung, R. C. M. \& Kamat, P. V. An inorganic hole conductor for organo-lead halide perovskite solar cells. Improved hole conductivity with copper iodide. J. Am. Chem. Soc. 136, 758-764 (2014).

22. Kim, H.-S. et al. High efficiency solid-state sensitized solar cell-based on submicrometer rutile $\mathrm{TiO}_{2}$ nanorod and $\mathrm{CH}_{3} \mathrm{NH}_{3} \mathrm{PbI}_{3}$ perovskite sensitizer. Nano Lett. 13, 2412-2417 (2013).

23. Dharani, S. et al. High efficiency electrospun $\mathrm{TiO}_{2}$ nanofiber based hybrid organic-inorganic perovskite solar cell. Nanoscale 6, 1675-1679 (2014).

24. Son, D.-Y., Im, J.-H., Kim, H.-S. \& Park, N.-G. 11\% Efficient perovskite solar cell based on $\mathrm{ZnO}$ nanorods: an effective charge collection system. J. Phys. Chem. C 118, 16567-16573 (2014)

25. Bi, D. et al. Efficient and stable $\mathrm{CH}_{3} \mathrm{NH}_{3} \mathrm{PbI}_{3}$-sensitized $\mathrm{ZnO}$ nanorods array solid-state solar cells. Nanoscale 5, 11686-11691 (2013)

26. Kumar, M. H. et al. Flexible, low-temperature, solution processed $\mathrm{ZnO}$-based perovskite solid state solar cells. Chem. Commun. 49, 11089-11091 (2013).

27. Ball, J. M., Lee, M. M., Hey, A. \& Snaith, H. J. Low-temperature processed mesosuperstructured to thin-film perovskite solar cells. Energy Environ. Sci. 6 1739-1743 (2013).

28. Malinkiewicz, O. et al. Perovskite solar cells employing organic charge- transport layers. Nat. Photonics 8, 128-132 (2014).

29. Liu, D. \& Kelly, T. L. Perovskite solar cells with a planar heterojunction structure prepared using room-temperature solution processing techniques. Nat. Photonics 8, 133-138 (2014).

30. Liang, P.-W. et al. Additive enhanced crystallization of solution-processed perovskite for highly efficient planar-heterojunction solar cells. Adv. Mater. 26, 3748-3754 (2014).

31. Jeng, J.-Y. et al. $\mathrm{CH} 3 \mathrm{NH} 3 \mathrm{PbI} 3$ perovskite/fullerene planar-heterojunction hybrid solar cells. Adv. Mater. 25, 3727-3732 (2013)

32. Saliba, M. et al. Influence of thermal processing protocol upon the crystallization and photovoltaic performance of organic-inorganic lead trihalide perovskites. J. Phys. Chem. C 118, 17171-17177 (2014).
33. Conings, B. et al. Perovskite-based hybrid solar cells exceeding $10 \%$ efficiency with high reproducibility using a thin films sandwich approach. Adv. Mater. 26, 2041-2046 (2014)

34. Eperon, G. E., Burlakov, V. M., Docampo, P., Goriely, A. \& Snaith, H. J. Morphological control for high performance solution-processed planar heterojunction perovskite solar cells. Adv. Funct. Mater. 24, 151-157 (2014).

35. Wolf, S. D. et al. Organometallic halide perovskite: Sharp Optical Absorption Edge and its relation to photovoltaic performance. J. Phys. Chem. Lett. 5, 1035-1039 (2014)

36. Mohammed, I. M., Elbadawi, A. A. \& Abuellhassan, H. H. Temperature and grain size effect on the electrical conductivity of $\mathrm{La}_{0.67} \mathrm{Ca}_{0.33} \mathrm{MnO}_{3}$. Journal of Applied and Industrial Sciences 1, 12-22 (2013).

37. Baikie, T. et al. Synthesis and crystal chemistry of the hybrid perovskite $\left(\mathrm{CH}_{3} \mathrm{NH}_{3}\right) \mathrm{PbI}_{3}$ for solid-state sensitised solar cell applications. J. Mater. Chem. A 1, 5628-5641 (2013).

38. Sun, S. et al. The origin of high efficiency in low-temperature solution-processable bilayer organometal halide hybrid solar cells. Energy Environ. Sci. 7, 399-407 (2014).

39. Noh, J. H., Im, S. H., Heo, J. H., Mandal, T. N. \& Seok, S. I. Chemical Management for colorful, efficient, and stable inorganic-organic hybrid nanostructured solar cells. Nano Lett. 13, 1764-1769 (2013).

40. Abate, A. et al. Lithium salts as "redox active" p-type dopants for organic semiconductor and their impact in solid-state dye-sensitized solar cells. Phys. Chem. Chem. Phys. 15, 2572-2579 (2013).

41. Ono, L. K. et al. Air-exposure-induced gas molecule incorporation into spiroMeOTAD films. J. Phys. Chem. Lett. 5, 1374-1379 (2014).

42. Cappel, U. B., Daeneke, T. \& Bath, U. Oxygen-induced doping of spiro-MeOTAD in solid-state dye-sensitized solar cells and its impact on device performance. Nano Lett. 12, 4925-4931 (2012).

43. So, F. \& Kondakov, D. Degradation mechanisms in small-molecule and polymer organic light-emitting diodes. Adv. Mater. 22, 3762-3777 (2010).

44. Hermenau, M. et al. Water and oxygen induced degradation of small molecule organic solar cells. Sol. Energy Mater. \& Sol. Cells 95, 1268-1277 (2011).

45. Abate, A. et al. Supramolecular halogen bond passivation of organic-inorganic halide perovskite solar cells. Nano Lett. 14, 3247-3254 (2014).

46. Barkhouse, D. A. R., Pattantyus-Abraham, A. G., Levina, L. \& Sargent, E. H. Thiols passivate recombination centers in colloidal quantum dots leading to enhanced photovoltaic device efficiency. ACS Nano 2, 2356-2362 (2008).

47. Lira-Cantu, M., Norrman, K., Andreasen, J. W. \& Krebs, F. C. Oxygen release and exchange in niobium oxide MEHPPV hybrid solar cells. Chem. Mater. 18 5684-5690 (2006)

48. Chen, Q. et al. Controllable self-induced passivation of hybrid lead iodide perovskites toward high performance solar cells. Nano Lett. 14, 4158-4163 (2014).

\section{Acknowledgments}

This work was supported by the RGC Theme-based Research Scheme (Grant number: HKU T23-713/11).

\section{Author contributions}

C.S. proposed and supervised the whole project. Z.R. contributed to the device fabrication and process optimization for the entire project. A.B.D., W.W.-F.L. and W.K.C. involved the discussion of the experiments. Q.S. and A.N. assisted the preparation of experiments. J.W. and L.Y. prepared the solution of $\mathrm{TiO}_{2}$. Q.S. carried out the XRD and spiro-MeOTAD resistance measurement. H.C.G. performed the characterization of prepared films by AFM. Y.W.-K. examined the film morphology by SEM. J.H. and G.B. conducted the measurement of time-resolved photoluminescence. A.N. carried out the EQE measurement and wrote the manuscript

\section{Additional information}

Supplementary information accompanies this paper at http://www.nature.com/ scientificreports

Competing financial interests: The authors declare no competing financial interests How to cite this article: Ren, Z. et al. Thermal Assisted Oxygen Annealing for High Efficiency Planar $\mathrm{CH}_{3} \mathrm{NH}_{3} \mathrm{PbI}_{3}$ Perovskite Solar Cells. Sci. Rep. 4, 6752; DOI:10.1038/ srep06752 (2014)

This work is licensed under a Creative Commons Attribution 4.0 International License. The images or other third party material in this article are included in the article's Creative Commons license, unless indicated otherwise in the credit line; if the material is not included under the Creative Commons license, users will need to obtain permission from the license holder in order to reproduce the material. To view a copy of this license, visit http://creativecommons.org/licenses/by/4.0/ 